\title{
Linguistic ridicule as a reflection of the confrontation between the political power and society
}

\author{
Alla Kornienko \\ Russian Academy of Sciences, Russia \\ av.kornienko@mail.ru
}

\begin{abstract}
This paper presents the words, collocations, and expressions which have been announced as winners of the Word of the Year contest, held on an annual basis in Russia for the last 12 years. Taken together, all these lexical units allow us to draw conclusions about some current trends in the modern-day Russian public discourse, namely its explicit politicization, increased emotionality, and the use of word play in an indirect dialogue with the political authorities. The inner meaning of word play, which is particularly widespread in social networks, represents the users' critical attitude, aiming to undermine conventional values through ridicule. Illustrative examples reflecting the views of the Facebook community (winners of the "Word of the Year") are cited in the paper.
\end{abstract}

Keywords: Facebook discourse, word of the year, ridicule, indirect dialogue with authorities.

\section{The Word of the Year contest in Russia}

Social networks, including Facebook, which will be discussed later, have rapidly invaded our daily life, and have become an open channel for indirect dialogue between society and authorities. This is confirmed by the results of the annual Word of the Year contest, held in Russia for the past 12 years. Here we outline the details of the contest. The internationally acclaimed event has been held in Russia since 2007. The contest was initiated and is curated by the prominent philologist, philosopher and culturologist Epstein. The purpose of the contest is to identify words, expressions and phrases that have acquired notoriety over the monitoring period and have elicited a public response. Entries can include lexical units already rooted in the language, as well as neologisms that have appeared in the current year. In the opinion of the contest organizers, the issues reflect the true mindset of Russian people, and serve as indicators of the emotional and intellectual state of society (Epstein 2013a).

There are several nominations in the contest: the first two, which are Word of the Year and Expression/Phrase of the Year are focused on lexical units already existing in the language, while the third nomination, that is Neologisms deals with newly coined words and expressions. As decided by the experts, the following words have won the contest over the years: 
- наукопомрачение (naukopomracheniye) in 2013 - this coinage is based on the Russian noun умопомрачение (insanity, lunacy) and it implies the insanity of science. The neologism combines the Russian наука (nauka) meaning 'science' and помрачение (pomracheniye), 'obscuration' in English ;

- гоn-политика (gop-politika) in 2017 that is politics using hoodlum demagogy in argumentation. The word combines the Russian zon (gop) as an interjection in the slang of street gangs and политика (politica) meaning 'politics';

- пенсиянин (pensiyanin) in 2018 which is a portmanteau word combining the Russian пенсия (pensiya), 'pension' in English and россиянин (rossiyanin), 'citizen of Russia', a word denoting a Russian who has to survive until their old-age pension.

The following phrases were the winners in the Expression/Phrase of the Year nomination:

- распил и откат (raspil i otkat) - carve-up and kickback. The phrase is used for corruption schemes involving the illegal exploitation of resources and consensual bribery;

- отечество в госбезопасности (otechestvo v gosbezopasnosti) - the homeland is in the hands of state security apparatus. The phrase is based on a reinterpretation of the popular slogan «Родина в опасности» (Rodina v opasnosti) "the homeland is in danger", where "danger" is replaced by its antonym "security", which is narrowed down to a "state security apparatus", implying government forces;

- вперед в темное прошлое (vpered v temnoye proshloye) - forwards to the dark past and is a playful conversion of the motto "Forwards into the Radiant Future" into a slogan announcing a return to the stagnant past.

The theoretical basis of the contest is the concept of keywords for the present moment proposed by Tatyana Shmeleva. According to this concept, the words which reflect the overall atmosphere of our time can be distinguished in public discourse, and so they represent verbally a portrait of the present moment. Words of the year are selected on the basis of a number of parameters, which are: the frequency of the word in public discourse, its developed syntagmatics and paradigmatics, as well as the existence of word derivations and its involvement in word play (Shmeleva 1993: 34-38). The contest material is collected over the course of one year through Facebook. Approximately three thousand Facebook users participanting in the data collection are organized into two groups, conventionally named "Word of the Year" and "Neologism of the Year". The lexical units selected by these groups are recorded along with the context of their usage. By the end of the monitoring period, the competition moderators classify and systematize them according to the frequency principle, after which the Expert Council begins their work. The Council includes 18 scholars from humanitarian disciplines: linguists, cultural scientists, psychologists, sociologists, writers, and journalists. Following a specially developed and formalized procedure, and working to the parameters set out above, the experts nominate competition winners in all categories. 


\section{Word of the Year contest winners and their key features}

\subsection{The purpose and methodological background of the study of words of the year}

We have examined the whole array of all winners over the period since the contest began 12 years ago. The list contains 264 lexical units, including words, expressions and phrases from the three nominations. Each lexical unit was examined for three acceptance criteria. The first criterion is that the lexical unit should be related to the political sphere of public life, as a response to the words or actions of the political authorities in Russia; the second criterion: it should incorporate an evaluative aspect; the third criterion is that it should involve ridicule.

Such a testing procedure conforms to the key aim of the study: to verify the hypothesis that in the absence of direct dialogue between the power and the society, Facebook became the channel for expressing disagreement with the official policy pursued by the authorities. Thus, the study is intended to reveal trends which manifest themselves in the prize-winning words of the contest, and the information obtained may indicate the confirmation or refutation of the initial hypothesis.

\subsection{Political orientation of the words of the year}

A survey of the contest's winners in different years discloses a number of key inherent features. Firstly, the winners of the contest, as a rule, represent a response by Facebook users to current political events, to statements and/or actions of the authorities. So, the contest of 2018 was notable for such neologisms as:

- пенсиянин (pensiyanin) - a Russian who has to survive until their old-age pension;

- выборрариум (vyborrarium) - a portmanteau composed of выборы (vybory) - election - and террариум (terrarium) - terrarium, ultimately denoting a polling station; the word connotes a foul, scandalous election campaign.

The winning lexical items in previous contests (наукопомрачение, гоп-политика, распил и откат, вперед в темное прошлое, отечество в госбезопасности) also display denotative references to politics. Evidence demonstrates the politicization of Facebook discourse and fits well with the pervasive politicization of science, education, and culture as a whole that is currently observed in Russia (Epstein 2013b).

\subsection{Negative charge of the words of the year}

The second feature of the winners' variety is its powerful negative effect. A clear majority of words and expressions of the year carry strong negative charge, reflecting the criticism of power elites by Facebook users. Moreover, this negative charge is not introduced by the context, but rather, is inherent to lexical meaning of words, that we see, for example, in the words " evil", "'misfortune', "'monster", "catastrophe', "'trouble', and many others.

The vast majority of the contest winners are pragmemes, or lexical units with a coupled referential/estimative meaning. In other words, a pragmeme is a lexeme with a fixed evaluative attitude (Epstein 1991: 31). While ordinary words acquire evaluative weight from their context, pragmemes are by their very nature evaluative. Context may only strengthen or reduce the inherent evaluative capacity of a pragmeme, but it cannot eliminate such a property entirely.

Examples of pragmemes are помрачение (pomracheniye) - obscuration, война (voyna) warfare, скандал (skandal) - scandal, антисиротский (antisirotskiy) - anti-orphan, which are the components included in the contest-winning words and expressions наукопомрачение 
(naukopomracheniye) - obscuration of science, гибридная война (gibridnaya voyna) - hybrid warfare, допинговый скандал (dopingovyy skandal) - doping scandal, антисиротский закон (antisirotskiy zakon) - anti-orphan law. These and many other pragmemes in the corpus of the selected contest winners confirm critical attitudes that Facebook users express to the decisions of the authorities. This extra-linguistic factor gives negative energy to the words of the year.

\subsection{Ridicule as a key feature of the words of the year}

The third distinctive feature observed in a large proportion of the material collected and analysed is blatant ridicule, that is, one of the forms of word play. This becomes especially evident in new words, expressions, and phrases that appeared as a verbal response to ongoing political events, which can be considered as clear evidence of the word-building capabilities of Facebook users. Russian dictionaries define the term "ridicule" as "an offensive joke about someone, something' (Kuznetsov 1998: 600). Linguists include at least three elements in the semantic formula of the term: 1) a joke, 2) giving offence, 3 ) interpreting its object facetiously (Karasik 2013: 117). Scholars emphasize the intentional quality of ridicule which is charged with the vigour of the communicator's oppositional attitude towards an object of ridicule (Karasik 2013: 126).

Among the winners of the contest there are such words and expressions as: здравохоронение, проФАНация науки, наукопомрачение, зломенитый, leaving no doubt about their pointedly mocking and playful nature. The compound word здравохоронение (zdravokhoroneniye) - health burial - is semantically close to the metaphor хоронить здоровье (khoronit' zdorov'ye) - to bury health - and it is an antithesis of the lexical item здравоохранение (zdravookhraneniye) - healthcare.

The second expression проФАНация науки (proFANatsiya nauki) - proFANation of science - connotes desecration, perversion of science as a system of knowledge. Also, it includes the abbreviation FANO, standing for the Federal Agency for Scientific Organizations, which covers the functions of the Academy of Sciences. After the establishment of the Agency, the administration of science shifted from scientists to functionaries, with dire consequences. The affair was acidly labelled by Facebook users as наукопомрачение (naukopomracheniye) - a new word combining the Russian наука 'science' and помрачение 'obscuration', and implying the insanity of science.

The last of the lexical units mentioned - зломенитый (zlomenityy) is a portmanteau blend of the adjective знаменитый (znamenityy) - eminent - and the noun зло (zlo) - evil. It is used as a negative tag for a politician who became notorious for his dishonourable deeds (cf. amateurish English form '"evilnent'”).

As a permanent member of the Expert Council of the Word of the Year contest, I am directly involved in the selection of contest winners, so I have at my disposal the complete body of data accumulated during the monitoring period. This allows me to conduct further investigation into the nuanced picture of the contest, and to focus on the contestant lexical units which, although unsuccessful, were close to the top spot. Such an analysis confirmed the revealed trend of a playful mocking response to the current political situation. The trend is embodied, for example, in the words denoting a favourite source of profit for officials карманизация (karmanizatsiya) - the embezzlement of budget funds to line the pockets of officials, literally - "pocketization"; and распилократия (raspilokratiya) - cutting resources for their own benefit - from распил (raspil) - cutting - and кратия (kratiya) - corresponding to the English "-cracy" - rule or government. As well as гиподержава (gipoderzhava) - labelling a global power in its decline - combination of Russian гипо (hypo) - hypo as a prefix - and держава (derzhava) - power, 
state, empire, or инополитянин (inopolityanin) with components ино (ino) - alien - and политянин (misspelled word for politician) - the designation of a functionary who looks at life as if from an alien planet.

According to experts (M. Epstein, V. Karasik), ridicule may be a manifestation of verbal aggression, but at the same time it is often associated with a person's passive reaction: their dull agreement, weariness, frustration, lack of confidence in positive changes. Ridicule may serve as a means of self-assertion for the communicator and as a tool for subduing their fears, and it can also be seen as a weapon pointed against pathos and undue pomposity in statements made by the authorities (Epstein 2013b). In all cases, ridicule functions in the same way: as a form of a word play aimed at reducing evaluation meanings, it always intentionally lowers the appraisal of a message (Karasik 2013: 126).

The words of the year are imbued with ridicule, and this shows that there is a distinct segment of social network users who disagree with official statements, executive decisions enacted and implemented by the authorities, and with authorized policy as a whole. Moreover, alternative designations of real facts in public life circulated on Facebook are connected directly in their majority to facts of native reality, domestic and foreign Russian politics. An additional barometer of the distance maintained by Facebook communication from the official discourse of the authorities is the category "Leitmotiv of the year", introduced recently into the contest schedule. This category covers those winners in all nominations which reveal a general idea. For example, in 2018 the leitmotiv was the confrontation between the government and the society which was associated with victims of pressure applied by the authorities (Skripals poisoning), and with some notorious judicial proceedings being instituted (case of Kirill Serebrennikov)

\subsection{Russian origins of words of the year}

Finally, another common feature of contest winners is their obvious "Russianness". According to linguists, many native speakers of Russian today are worried about the vast number of loan words that have recently penetrated their native tongue (Plungyan 2018: 224; Shcherbinina 2015: 12). The unrestrained torrent of lexical borrowings also worries language analysts, who believe that the incorporation of loan words partially transforms the structural basis of the Russian mentality (Kolesov 2002: 202). However, a study of winning neologisms shows that nearly all of them are built solely on Russian word-building rules, i.e. they are generated according to Russian formative patterns complying with the derivative rules of Russian grammar.

The political derivations built up on the material of the contest winners are extremely diversified. Different techniques of word play find their places here: a pattern of failed expectation (наукопомрачение - tying together science and mental insanity), logical inconsistency (вперед в темное прошлое - forwards to the dark past), playing upon the meaning of big names (кадыринг - kadyring, from Kadyrov - implying a person's political reinforcement), oxymorons (Госдура - gosdura - the State Duma/ the State Fool (a woman) a mocking characterisation of Госдума - the Gosduma - the supreme legislative body of the state), and word play with fixed expressions (хотели как лучше, а получилось навсегда khoteli kak luchshe, a poluchilos' navsegda - We wanted it to be as good as possible, but it turned out to be forever). Thus, Viktor Chernomyrdin's popular quotation (хотели как лучше, а получилось как всегда - khoteli kak luchshe, a poluchilos' kak vsegda - We wanted it to be as good as possible, but it turned out as always - which attests further misfortune is pronounced now as a verdict: this is forever. 
It is clear that only some lexical creations of Facebook users will be incorporated into the active vocabulary of the modern Russian language. However, neologisms appearing in this domain provide some evidence for the presence of problems in contemporary Russian society.

\section{Conclusion}

And so, contest winners - the words, collocations and phrases of the year, which reflect the overall atmosphere of our time, and represent verbally a portrait of the monitored year, are imbued with critical zeal and ridicule, reflecting an idea of confrontation with the authorities that confirms the initial hypothesis of the study. Facebook communicators associated with the opposition regularly declare their critical stance towards authorities through a word play that produces a comic effect, and in this context, the choice on users' part prefers, as the survey shows, not a mild joke, which is a basic verbal comic form (Sannikov 1999: 15), but rather its derivate launching the abasing scheme. Ridicule turns out to be the most strongly desired verbal response to the status quo, at a time when the authorities muddle up reality with ideal vision, and routinely convert "should be" into "is" and vice versa.

This indirect dialogue with the authorities through ridicule, presents one social group involved in a word play aimed at reducing evaluation meanings. This play may end with a drastic turnover of value scale, when the positive pathos of official statements changes to its opposite. So здравоохранение - healthcare - converts into здравохоронение - health burial, and the abbreviation $\Phi A H O$ - FANO, the Federal Agency for Scientific Organizations converts into проФАНацию науки - proFANation of science.

Such evaluative inversions, which are an instantaneous collective reaction to current events and trends of political life, can be found in specific publications dealing with Russian anecdotes of Soviet and post-Soviet period (Graham 2003; Shmeleva, Shmelev 2002). Seth Graham, referring to Dora Shturman and Sergey Tiktin, ascertains the prevailing scepticism and nihilism, the "all-penetrating" and the "all-encompassing" nature of denial as an immanent characteristic of the Russo-Soviet anecdote (Graham 2003: 98). Such evaluative inversions are entirely in harmony with Russian speech culture, which is known for its increased emotionality and evaluative richness as one of its main characteristic features (Wierzbicka 1996: 33-34, 37; Leontovich 2005: 185). In addition, such evaluative inversions vividly illustrate a thesis formulated by Russian cultural scholars about the cardinal bi-polarity of Russian culture and demonstrate the existence of two evaluation poles with no evidence of a neutral axiological zone (Lotman, Uspenskiy 1996).

\section{References}

Epstein, M. (1991). Ideologiya i yazyk. Postroyeniye modeli i osmysleniye diskursa [Ideology and Language. Model Building and Thinking of Discourse]. Filosofskaya $i$ sotsiologicheskaya mysl 6, pp. 29-47.

Epstein, M. (2013a). Slova kak simvoly epokhi [Words as symbols of an epoch]. Snob. 05.01.2013. Retrieved August 05, 2019 from http://snob.ru/profile/27356/blog/70248\#comment_683001.

Epstein, M. (2013b). Yazyk - ne zerkalo obshchestva... Verbalnyye itogi 2013 [Language is not a mirror of society ... Verbal results 2013]. Retrieved August 3, 2019 from http://snob.ru/profile/27356/blog/70175\#comment_681703

Graham, S. B. (2003). A Cultural Analysis of the Russo-Soviet Anekdot. University of Pittsburgh. 
Karasik, V. I. (2013). Yazykovaya matritsa kultury [Language Matrix of Culture]. Moskva: Gnozis.

Kolesov, V. V. (2004). Yazyk i mental'nost' [Language and Mentality]. Saint-Petersburg: Peterburgskoye Vostokovedeniye.

Kuznetsov, S. A. (ed). (1998). Bolshoy tolkovyy slovar russkogo yazyka [Big Explanatory Dictionary of the Russian Language]. Saint-Petersburg: Norint.

Leontovich, O. A. (2005). Russkiye i amerikantsy: paradoksy mezhkul'turnogo obshcheniya [Russians and Americans: Paradoxes of Cross-cultural Communication]. Moskva: Gnozis.

Lotman, Y. M. \& Uspenskiy, B. A. (1996). 'Rol' dual'nykh modeley v dinamike russkoy kul'tury' [Role of Dual Patterns in Dynamics of Russian Culture], in Uspenskiy, B. A., Izbrannyye trudy T. 1. Semiotika istorii. Semiotika kul'tury. Moskva: Shkola «Yazyki russkoy kul'tury», pp. 338-380.

Plungyan, V. A. (2018). 'Yazyk. Budushcheye vremya' [Language. Future], in Vishnevetskaya, M. (ed.) Slovar' peremen - 2015-2016. Moskva: Tri kvadrata, pp. 223 228.

Sannikov, V. Z. (1999). Russkiy yazyk v svete yazykovoy igry [Russian Language in the Light of a Word Play]. Moskva: Yazyki russkoy kul'tury.

Shcherbinina, Y. V. (2015). Kniga - tekst-kommunikatsiya. Slovar'-spravochnik noveyshikh terminov i ponyatiy [Book - Text-Communication. Reference Dictionary of the Newest Terms and Concepts]. Moskva: FORUM: INFRA.

Shmeleva, E. Y. \& Shmelev, A.D. (2002). Russkiy anekdot: Tekst i rechevoy zhanr [Russian Anecdote. Text and Speech Genre]. Moskva: Yazyki slavyanskoy kul'tury.

Shmeleva, T. V. (1993). 'Klyuchevyye slova tekushchego momenta' [Keywords of the Present Moment]. Collegium 1, pp. 33-41.

Wierzbicka, A. (1996). 'Russkiy yazyk' [Russian Language], in Wierzbicka, A. (ed.), Yazyk. Kul'tura. Poznaniye. Moskva: Russkiye slovari, pp. 33-88. 